\title{
Production, dynamics and demography of an Amphiura filiformis population
}

\author{
Mattias Sköld, Lars-Ove Loo, Rutger Rosenberg \\ University of Göteborg, Kristineberg Marine Research Station, S-450 34 Fiskebäckskil, Sweden
}

\begin{abstract}
Secondary production and population dynamics of the brittle star Amphiura filiformis (O. F. Müller) were studied between June 1990 and November 1991 at $40 \mathrm{~m}$ depth in the Skagerrak, west Sweden. Mean abundance of individuals $>1 \mathrm{~mm}$ in disc diameter was stable around 280 ind. $\mathrm{m}^{-2}$ After a spawning maximum in June and July, settling post-larvae (ca 7000 ind. $\mathrm{m}^{-2}$ ) occurred in autumn 1991. Disc growth and gonad production accounted for ca $68.9 \%\left(1.8 \mathrm{~g} \mathrm{AFDW} \mathrm{m}^{-2} \mathrm{yr}^{-1}\right)$ of the total annual production in the population. About $13.3 \%\left(0.34 \mathrm{~g} \mathrm{AFDW} \mathrm{m}^{-2} \mathrm{yr}^{-1}\right)$ of the total production was allocated to regeneration of arms, probably a result of cropping by predators. Mean regenerated biomass in percent of total biomass for adult $A$. filiformis was between 12 and $30 \%$ (mean $22 \%$ ). Annual production/biomass ratio was $0.46 \mathrm{yr}^{-1}$. The input of energy to arm regeneration indicates the importance of $A$. filiformis as an important food source.
\end{abstract}

KEY WORDS: Echinodermata A Amphiura filiformis - Secondary production - Growth - Regeneration Skagerrak

\section{INTRODUCTION}

Seasonal hypoxic conditions have been associated with decreasing benthic biomass in the Kattegat and coastal areas of the Skagerrak during the past $15 \mathrm{yr}$ (Josefson \& Rosenberg 1988, Rosenberg \& Loo 1988, Rosenberg et al. 1992). However, at some well-aerated sites total benthic biomass has increased (Pearson et al. 1985, Josefson 1990). Although some studies (e.g. Josefson 1990, Josefson \& Jensen 1992) have suggested that higher rates of energy transformations from the pelagic to benthic environments are causing large-scale changes in benthic productivity, secondary production of many benthic species has not been measured. One of the dominant species contributing to biomass increases in parts of the Kattegat-Skagerrak system is the brittle star Amphiura filiformis (O. F. Müller), which often number in the hundreds per $\mathrm{m}^{2}$ on silt-clay bottoms from ca 20 to $50 \mathrm{~m}$ depth (Petersen 1913, Josefson \& Jensen 1992).

Long-term studies in Galway Bay on the west coast of Ireland have shown that low annual recruitment, stable densities and stationary size distributions are characteristics of Amphiura filiformis populations in that area (O'Connor et al. 1983). This species also pro- vides an important link between the benthic and pelagic environments because it seems to be important in the diets of many fish and invertebrate predators including dab Limanda limanda (Duineveld \& Noort 1986), haddock Melanogrammus aeglefinus (Mattson 1992) and Norwegian lobster Nephrops norvegicus (Baden et al. 1990). These predators do not generally consume the entire brittle star but crop only the arms, which are later regenerated. An energy budget estimated for the $A$. filiformis population of Galway Bay suggested that arm regeneration contributed significantly to the total annual production of this species (O'Connor et al. 1986).

In this paper we report on the population and production dynamics of Amphiura filiformis at a site located in the Kattegat-Skagerrak system along the Swedish coast. The study includes the contribution of arm regeneration in relation to the total annual production of this species.

\section{MATERIAL AND METHODS}

All sampling was conducted at the mouth of the Gullmarsfjord, west Sweden $\left(58^{\circ} 14.72^{\prime} \mathrm{N}, 11^{\circ} 25.80^{\prime} \mathrm{E}_{\text {; }}\right.$ 


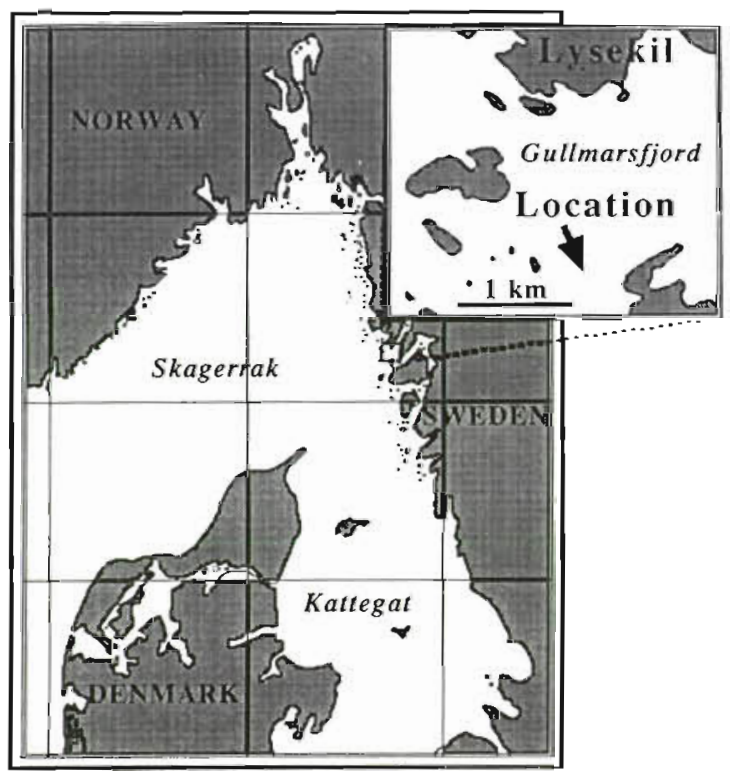

Fig. 1. Location of sampling stations

Fig. 1), at $40 \mathrm{~m}$ depth during June 1990 to November 1991, where a 'typical' Amphiura filiformis community (sensu Petersen 1913) has been monitored annually since 1983. The top sediment layer (0 to $1 \mathrm{~cm}$ ) had the following mean values based on sediment dry weight: organic matter, $3.5 \%$ (standard deviation $=0.3, \mathrm{n}=24$ ) organic $\mathrm{C}, 2.4 \%(\mathrm{SD}=0.3, \mathrm{n}=24) ; \mathrm{N}$ content, $0.3 \%$ $(\mathrm{SD}=0.04, \mathrm{n}=24)$. The sediment had a grain-size distribution with 2 peaks, one clay-silt at 2 to $8 \mu \mathrm{m}(47 \%)$ and one silt-very fine sand at 63 to $125 \mu \mathrm{m}(38 \%)$. The water content varied around $59 \%$ of wet weight (Tunberg 1990). Salinity at $40 \mathrm{~m}$ depth, close to the sampling site, was between 30 and 34 psu. Temperature was lowest in March, $4.6^{\circ} \mathrm{C}$, and increased until the beginning of October, when a maximum of $13.8^{\circ} \mathrm{C}$ was recorded. Oxygen concentrations exceeded $3.8 \mathrm{ml}$ $\mathrm{O}_{2} \mathrm{l}^{-1}$ (Lindahl et al. 1991).

Sampling. Quantitative benthic faunal and sediment samples were collected at 2 to 3 wk intervals from 14 June 1990 to 4 November 1991. Samples were taken with a modified $\left(0.012 \mathrm{~m}^{2}\right)$ HAPS coirir (Kanneworf \& Nicolaisen 1973) with 10 replicates to fulfil the criterion of sampling precision set at a standard error (SE) $<25 \%$ of the mean for abundance and biomass of Amphiura filiformis.

The brittle stars were gently rinsed and picked out from the sediment cores with forceps and then preserved in $95 \%$ ethanol to avoid autotomisation of arms. When no more ophiuroids were visible, the remaining sediment was gently sieved on a $1 \mathrm{~mm}$ screen and sieve contents preserved in $70 \%$ ethanol to be sorted later at $6 \times$ magnification under a dissecting microscope. An ocular micrometer was used to measure oral width to the nearest $0.1 \mathrm{~mm}$ according to $\mathrm{O}^{\prime}$ Connor et al. (1983). Oral width was used as a measurement of size because it has been shown to be less variable than disc size, which changes seasonally due to gonad development ( $\mathrm{O}^{\prime} \mathrm{Connor}$ et al. 1983). To estimate secondary production the brittle stars were separated into 4 categories; discs, whole arms, cut arms and regenerated arms (see Fig. 2). These categories were counted and weighed individually after drying to constant weight (DW) at $60^{\circ} \mathrm{C}$.

Samples for studies of recruitment of Amphiura filiformis were collected from 25 March 1991 to 4 November 1991 by taking 2 box core samples $\left(0.1 \mathrm{~m}^{2}\right)$ and, from each of them, subsampling 3 replicates with a plexiglass tube (50 $\mathrm{mm}$ internal diameter) to $40 \mathrm{~mm}$ depth. The sediments were kept in plastic jars with $95 \%$ ethanol and sorted later at $12 \times$ magnification after being rinsed in distilled water over a $0.20 \mathrm{~mm}$ sieve.

Total $C$, organic $C$ and total $N$ contents of the top sediment layer $(0$ to $1 \mathrm{~cm}$ ) were measured from 2 replicate HAPS corers taken at 2 to $3 w k$ intervals from 21 August 1990 to 4 November 1991. Samples were freeze-dried and homogenised prior to analysis. After removal of inorganic carbon according to Hedges \& Stern (1983), the sediment organic $\mathrm{C}$ and $\mathrm{N}$ were determined with a Carlo Erba NA $1500 \mathrm{C} / \mathrm{N}$ analyser. Grain size analyses were carried out by the pipette method (Krumbein \& Pettijohn 1938).

Size-frequency distributions. To investigate size distributions of Amphiura filiformis retained by the $1 \mathrm{~mm}$ sieve, sampling was undertaken on 13 September 1990, 18 March 1991 and 4 November 1991 using a Smith-McIntyre grab $\left(0.1 \mathrm{~m}^{2}\right)$. Six to ten grab samples were taken on each date in order to collect at least 200 individuals for measuring the oral width. Analysis was done with the method described by MacDonald \& Pitcher (1979). This method finds the best fit of a normal distribution mixture with a specified number of components, using maximum likelihood estimation for grouped data to obtain mean oral width, standard deviation and the proportion of each size-group component

Statistics and calculations. Temporal variation in abundance was examined with nested 1-way ANOVA (Morrisey et al. 1992). Comparison. for evaluating changes between short and long time periods for the total abundance was undertaken by nesting 3 consecutive sampling occasions, comparing them with each other and nested over longer periods. First, 2 wk periods were analysed nested over 6 mo periods, then 1 mo periods were analysed nested over 5 mo periods.

The temporal changes in the abundance of postlarvae were tested with nested 1-way ANOVA (Underwood 1981) by nesting the subsamples from the replicates of each sampling occasion. 
Spatial distribution (index of dispersion) was tested according to Elliott (1977) with a $\chi^{2}$ test for agreement with a Poisson series as the null hypothesis at $95 \%$ probability level.

Biomass was tested for effect of time with 1-way ANOVA. Data were corrected for homoscedasticity by the $X^{1 / 2}$ transformation because the variance was approximately equal to the mean (Sokal \& Rohlf 1981), and tested for the presence of gross heterogeneity of variances with Cochran's test (Underwood 1981)

Logarithmic means of individual biomass of separated size groups were used to test if individuals grew exponentially by simple regression of the means and $95 \%$ confidence limits for the slope of the line.

Regenerated biomass (\%), which is the animal's regenerated biomass in proportion to the total biomass of the animal, was tested for temporal changes with 1-way ANOVA. Data were corrected for homoscedasticity by the arcsine transformation as recommended for proportions (Sokal \& Rohlf 1981) and tested for the presence of gross heterogeneity of variances with Cochran's test (Underwood 1981).

To estimate production $(P)$, the Amphiura filiformis population was separated into 3 size groups according to the MacDonald \& Pitcher method described above. Size group 1 (SG 1) had a mean oral width of $1.3 \mathrm{~mm}$ that increased to $1.7 \mathrm{~mm}$ during the period $13 \mathrm{Sep}$ tember 1990 to 18 March 1991, and SG 2 increased from 1.8 to $2.1 \mathrm{~mm}$ over that same period. SG 3 had a mean oral width of $2.4 \mathrm{~mm}$ during the entire period. Methods for calculating production are illustrated in Fig. 2. $P$ for SG 1 and SG 2 was calculated according to Crisp (1984) (see Eq. 1) because these individuals lacked gonads and rarely had regenerated arms. Production was only calculated for these groups when separable (from 13 September 1990 to 18 March 1991); when not separable, they were considered incorporated into SG 3 and production calculated as shown below. Due to low densities of these groups when sampled with the HAPS core, abundance $(N)$ and mean biomass increment $(w)$ between successive SmithMcIntyre grab samples on 13 September and 18 March (t) were used to give a quantitative abundance with higher precision of these size groups. Variation in abundance between replicate grabs of these size groups was, however, considerable because of the low numbers. The biomass was calculated from the biometrical relationship between oral width and dry weight for the smaller size groups (see biometrical relationship in the results).

$$
P=\sum_{t=0}^{n} \frac{\bar{N}_{t}+\bar{N}_{t+1}}{2} \Delta \bar{W}
$$

We used Eq. (1) for calculating $P$ of the discs of the matured SG 3 , which were mainly in the range of the

\section{CALCULATIONS OF PRODUCTION FOR SIZE GROUP 3}

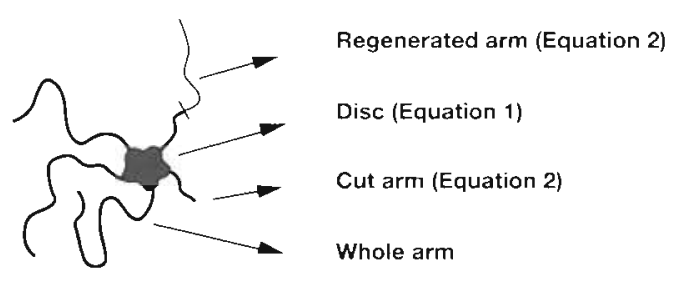

$\sum$ Total production

Fig. 2. Illustration of how production of different parts of the adult Amphiura filiformis size group (SG 3) were calculated. See text for equations

'asymptotic' size of Amphiura filiformis. Here the mean disc 'population' density $\left[\left(N_{t}+N_{t+1}\right) / 2\right]$ was kept constant at 280 ind. $\mathrm{m}^{-2}$ since the population density was constant at that value (see below). When production is calculated for SG 1 and SG 2 (from 13 September 1990 to 18 March 1991), $N$ is reduced by the number of these groups. $\Delta w$ is the individual mean disc weight increment between successive samplings.

Production of regenerating arms of SG 3 was calculated with a growth factor $\left(G_{\text {reg. }}\right.$ Eq. 2 ) based on the assumption that regeneration is an ongoing process and cropped arms have not reached their full length and width:

$$
P=\sum_{0}^{n} f G_{\mathrm{reg}} \Delta t
$$

where $f$ is the number of arms under regeneration, i.e. cut arms plus arms not fully regenerated from the SG 3 population. 'Not fully regenerated arms' is defined as the proportion of arms from the category 'regenerated arms' (Fig. 2) that do not have the same weight as whole arms. The latter was calculated by dividing the mean weight of regenerated arms by unbroken arms that did not show any sign of regeneration, and multiplying this proportion with the number of regenerated arms. This gives the proportion of arms not fully regenerated. The arms were treated as individuals and $G_{\text {reg }}$ is the growth increment of arms subsequent to cutting, measured in the laboratory on Amphiura filiformis as $9.68 \mathrm{~mm} 41 \mathrm{~d}^{-1}$ ( $\mathrm{SE}=1.06, \mathrm{n}=15$ ) (Andreasson 1990). Converting this to biomass by the biometrical relationship between regenerated arm length and dry weight (see below) gives an estimate of $G_{\text {reg }}$ of $0.0048 \mathrm{mg} \mathrm{DW}$ arm $\mathrm{mg}^{-1} \mathrm{~d}^{-1}$.

The weight-specific growth rate $\left(G, \% \mathrm{~d}^{-1}\right)$ was calculated from the equation $G=100\left(e^{\left[\ln Y_{T}-\ln Y_{t} Y /(T-t)\right.}-1\right)$ where $Y_{T}$ and $Y_{t}$ are the sizes at times $T$ and $t, T$ being later than $t$ (Ricker 1979). 
Gonad development was analysed by subjective, visual observation of the gonads under a dissecting microscope. We classified development into 3 categories 1: lack of gonads; 2: having gonads; and 3: full of probably ripe gonads.

\section{RESULTS}

\section{Population dynamics}

Estimated densities of Amphiura filiformis (captured in the $1 \mathrm{~mm}$ sieve) are shown in Fig. 3a. Mean density was stable around 280 ind $\mathrm{m}^{-2}$ over the sampled period. There was neither a significant difference in density between 2 wk periods [degrees of freedom factor and error $(\mathrm{df})=6,81 ; F$-value $(F)=1.96, \mathrm{p}>0.05]$ and nested 6 mo periods $(\mathrm{df}=2,81 ; F=0.51, \mathrm{p}>0.05)$, nor between 1 mo periods ( $\mathrm{df}=6.81 ; F=1.34, \mathrm{p}>0.05)$ and nested 5 mo periods ( $\mathrm{df}=2,81 ; F=0.11, p>0.05$ ).

Maximum mean settlement occurred in August to October 1991 (Fig. 4). Temporal changes were significant ( $\mathrm{df}=14,60 ; F=2.93, \mathrm{p}<0.05$ ) but no difference were found among the replicates at each time ( $\mathrm{df}=$ 15,$60 ; F=1.50, \mathrm{p}>0.05$ )

The spatial distribution of the Amphiura filiformis population was mainly random $\left(\chi^{2}\right.$-test, $\left.p>0.05\right)$ when

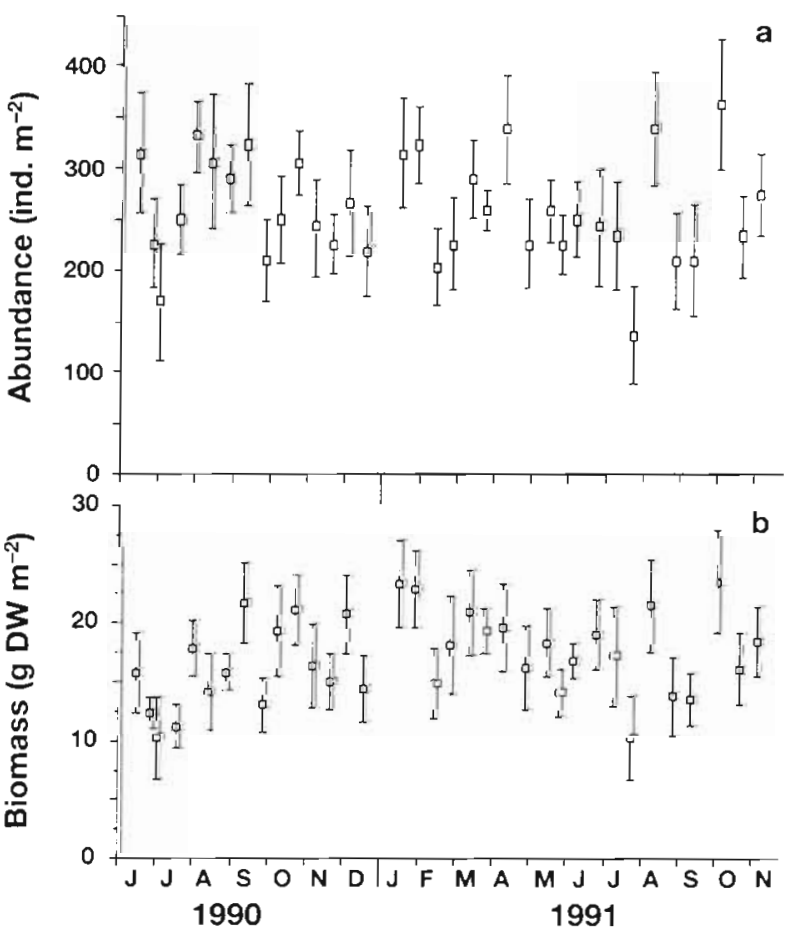

Fig. 3. Amphiura filiformis. (a) Mean ( $\$$ SE) abundance and (b) mean $\left( \pm \mathrm{SE}\right.$ ) biomass of brittle stars. Sample size: $0.012 \mathrm{~m}^{2}$, $\mathrm{n}=10$

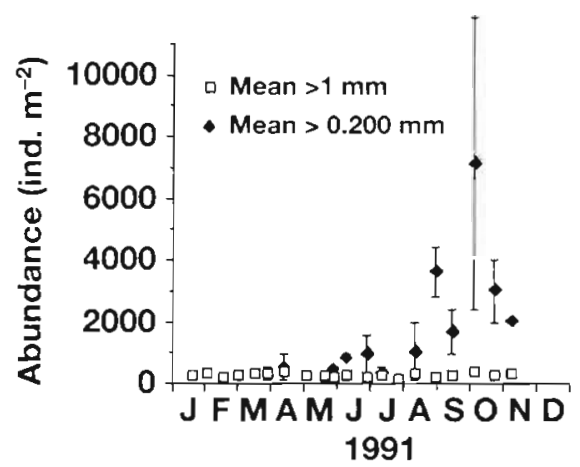

Fig. 4. Amphiura filiformis. Mean ( $\pm \mathrm{SE}$ ) abundance of adult and juvenile brittle star. Juveniles were sampled from 25 March 1991 Sample size: $0.012 \mathrm{~m}^{2}, \mathrm{n}=10$ and for juveniles $0.1 \mathrm{~m}^{2}, \mathrm{n}=2$, subsampled with a plexiglass tube with a diameter of $50 \mathrm{~mm}$

calculated for the HAPS samples $\left(0.012 \mathrm{~m}^{2}\right)$ taken from 14 June 1990 to 4 November 1991 . Because the index of dispersion is dependent on sample unit size, the index was also calculated using samples from the SmithMcIntyre grab $\left(0.1 \mathrm{~m}^{2}\right)$ on 13 September 1990,18 March

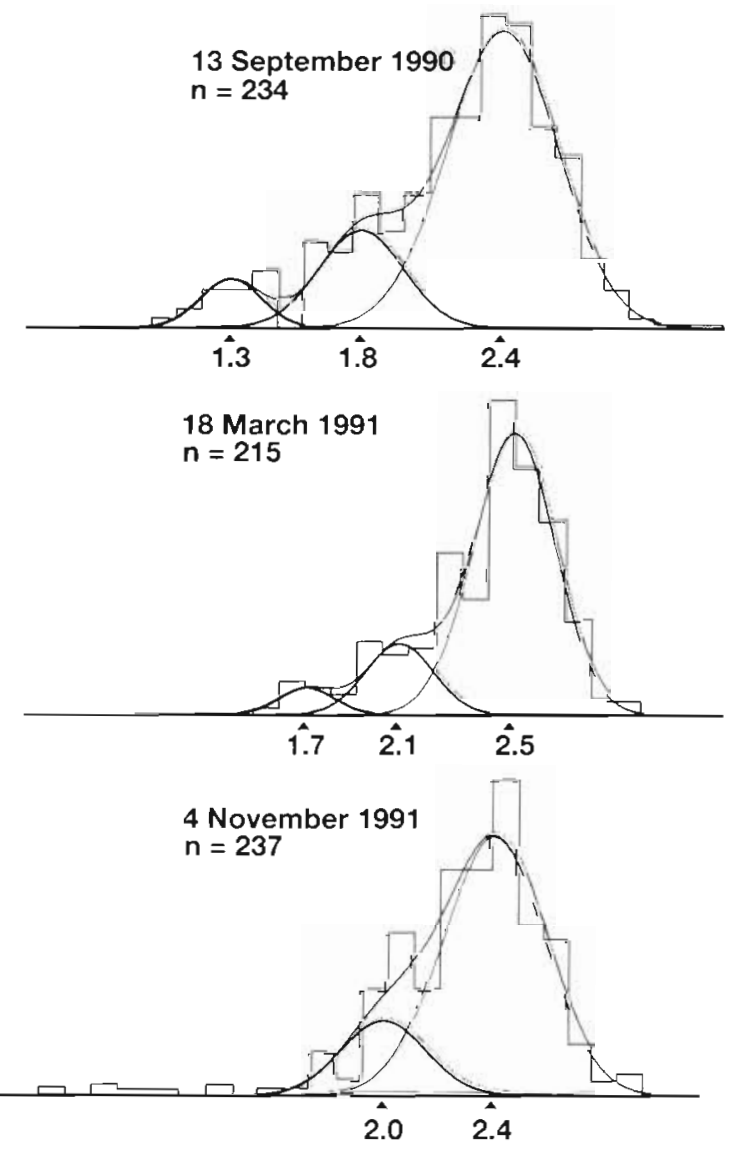

Fig. 5. Amphiura filiformis. Size-frequency distributions of oral width and best-fitted normal distributions. Mean width indicated for each distribution 
1991 and 4 November 1991. These results demonstrated a contagious distribution $\left(\chi^{2}\right.$-test, $\left.p<0.05\right)$.

Size-frequency distributions and the best-fitted normal distributions are shown in Fig. 5. The analysis detected 3 size groups on 13 September 1990 and on 8 March 1991, but only 2 on 4 November 1991. The 2 smaller groups, SG 1 and SG 2, showed a temporal increase in size, but the large group, SG 3, was relatively constant in size. No significant recruitment to these 3 size groups could be recognised between these periods in the HAPS corers sampled every second week.

The constant numerical density and the sizefrequency distributions showed that almost no recruitment to the adult Amphiura filiformis population took place during the investigation. The population was stable and few recruits were required to balance mortality losses in individuals $>1 \mathrm{~mm}$ (i.e. those captured in the $1 \mathrm{~mm}$ sieve), shown in the size-frequency histograms (Fig. 5). Most ( 75 to $80 \%$ ) of the population had reached their maximum size and could not be separated into size groups that correlated with age classes.

\section{Biometrical relationship}

The relationship between oral width and dry weight made it possible to calculate the biomass of SG 1 and SG 2 from the size-frequency histograms used for production estimates. A linear regression of $\log _{10} \mathrm{DW}$ ind.$^{-1}$ $(Y)$ on $\log _{10}$ oral width $(X)$ for these 2 size groups gave the following relationship: $Y=0.00218 X^{4.344}$ [square product moment correlation coefficient $\left(\mathrm{r}^{2}\right)=0.71$, significance level for the contribution of the model $Y=a X^{b}$ to the sum of squares, $p<0.001, \mathrm{df}=1,305$ ]. The relationship between arm length and dry weight was used to calculate daily regeneration rate $\left(G_{\text {reg }}\right)$. A linear regression of $\log _{10} \mathrm{DW} \operatorname{arm}^{-1}(Y)$ on $\log _{10}$ arm length $(X)$ for regenerated arms gave the following relationship: $Y=0.01056 X^{1.288}\left(\mathrm{r}^{2}=0.63\right.$, significance level for the contribution of the model $Y=a X^{b}$ to the sum of squares, $\mathrm{p}>0.001, \mathrm{df}=1,35)$.

Table 1. Linear regression analyses of means of individual biomasses with time at $95 \%$ confidence limits for the slope of regression line. n: no. of sampling dates containing each size group; s: slope of regression line; $r^{2}$ : square of product correlation coefficient; Sig.: level of significance; ns: non-significance $(p>0.05) ; \cdot p<0.05$; $\because p<0.01$

\begin{tabular}{|llrlll|}
\hline \multicolumn{1}{c}{ Period } & $\mathrm{n}$ & \multicolumn{1}{c}{$\mathrm{s}$} & \multicolumn{1}{c}{$\mathrm{r}^{2}$} & Sig. \\
\hline Total biomass & 14 Jun 1990 - 4 Nov 1991 & 35 & 0.00014 & 0.048 & ns \\
SG 1 & 14 Jun 1990 - 13 Mar 1991 & 9 & 0.0040 & 0.79 &. \\
SG 2 & 14 Jun 1990-13 Mar 1991 & 18 & 0.0020 & 0.64 &. \\
SG 3 & 14 Jun 1990 - 4 Nov 1991 & 35 & 0.00013 & 0.16 &. \\
\hline
\end{tabular}

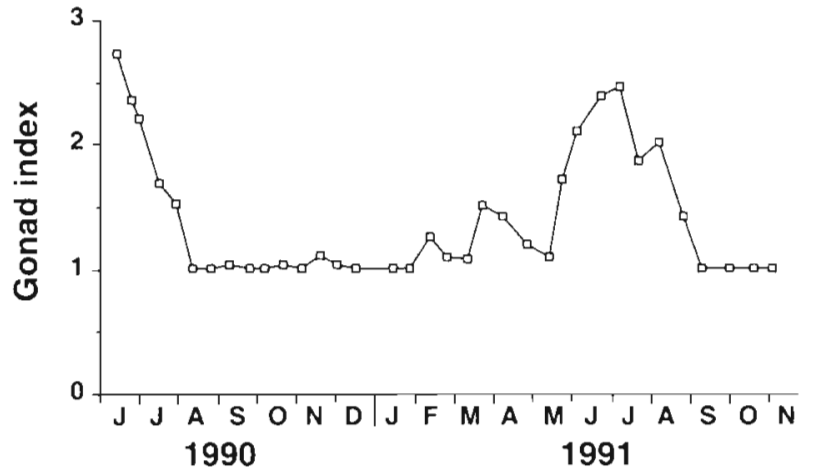

Fig. 6. Amphiura filiformis. Gonad development of brittle star. Values represent the mean indices of each date where 1: lack of gonads; 2: having gonads; and 3: full of probably ripe gonads

\section{Gonad development}

The gonad index (Fig. 6) indicated the presence of gonads from February to September 1991 with maxima in June to July in both 1990 and 1991. To study the spatfall a correlation analysis between gonad index and settling was performed. The best positive correlation was found with a time lag of $88 \mathrm{~d}(\mathrm{r}=0.81, \mathrm{n}=14)$.

\section{Growth and production}

The mean biomasses \pm SE obtained with the HAPS corer are shown in Fig. 3b. Biomass showed no temporal difference when tested with 1-way ANOVA (df $=34,315 ; F=1.24, p>0.05$ ). Linear regression analyses showed no trends for individual total biomass, but positive slopes of the regression lines $(p<0.05)$ for SG 1, SG 2 and SG 3 (see Table 1) demonstrate exponential increase in weight with time.

Mean individual regenerated biomass as a percent of total biomass for SG 3 was between 12 and $30 \%$ with an overall mean of $22 \%$ (Fig. 7). Temporal differences were significant ( $\mathrm{df}=34,744 ; F=2.43, \mathrm{p}<0.001$ ).

Based on growth of $\mathrm{SG} 1$ and SG 2, and the assumption that SG 3 represents an asymptotic size for Amphiura filiformis within this population, a growth curve based on the von Bertalanffy (1934) equation was constructed by extrapolation of the time series at this size class interval (Fig. 8). The curve was calculated from $L_{l}=$ $L_{\infty}-\left(\mathrm{L}_{\infty}-L_{0}\right) \mathrm{e}^{-K t}$, where $K$ is constant and $L_{\infty}$ and $L_{0}$, the maximum and minimum length respectively, 


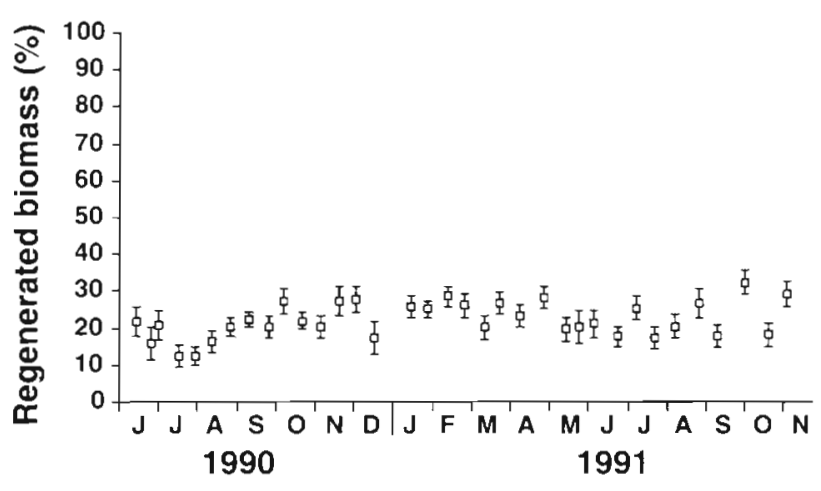

Fig. 7 Amphiura filiformis. Mean ( \pm SE) individual regenerated biomass of brittle star as a percentage of total biomass. Sample size: $0.012 \mathrm{~m}^{2}, \mathrm{n}=10$

are all derived from a Ford-Walford plot based on the yearly growth of SG 1 (Crisp 1984).

Growth was calculated for SG 1 and SG 2 for the periods when significant growth could be shown for mean individual biomass and somatic size (Table 1. Fig. 5). Estimates of size-specific growth rates for SG 1 and SG 2 were 0.66 and $0.38 \% \mathrm{~d}^{-1}$ respectively, recalculated to disc diameter from the biometrical relationship between oral width and disc diameter of Josefson \& Jensen (1992).

Production $(P)$ was estimated between each sampling interval as the sum of total growth of SG 1 and SG 2, plus $P$ of discs and regenerated production of arms of SG 3 . Disc production was calculated as positive biomass changes based on the assumption that negative biomass changes are caused by starvation or shedding of gonad products. If negative biomass changes are included, disc production is about zero $\left(-0.15 \mathrm{~g} \mathrm{DW} \mathrm{m}^{-2} \mathrm{yr}^{-1}\right)$. The cumulative production over the sampling period is shown in Fig. 9 and separated for these categories in Fig. 10. The total annual production was estimated from August 1990 to August 1991 as $9.46 \mathrm{~g} \mathrm{DW} \mathrm{m}^{-2}$. Converting this to ash-free dry weight (AFDW) and wet

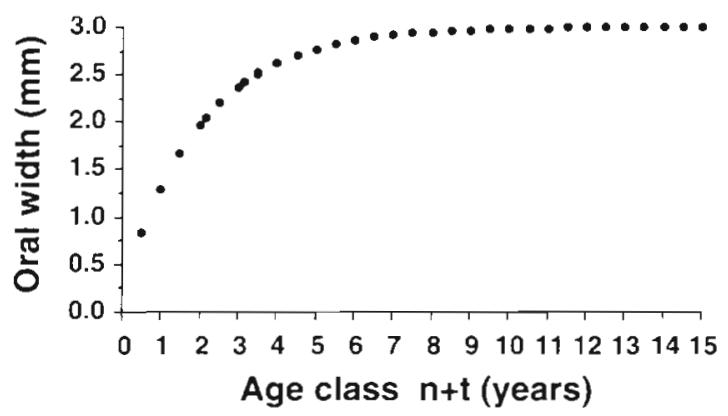

Fig. 8. Amphiura filiformis. Growth curve of brittle star calculated according to the von Bertalanffy equation weight (WW) according to biometrical relationships of individuals and arms (Josefson \& Jensen 1992) gives $2.59 \mathrm{~g} \mathrm{AFDW} \mathrm{m}^{-2} \mathrm{yr}^{-1}$ and $29.75 \mathrm{~g} \mathrm{WW} \mathrm{m}^{-2} \mathrm{yr}^{-1}$. For individuals, mean production was $0.0093 \mathrm{~g}$ AFDW ind. ${ }^{-1} \mathrm{yr}^{-1}$ and individual mean biomass was $0.020 \mathrm{~g}$ AFDW ind.$^{-1}$. For the whole population, the production to biomass $(P / B)$ ratio was $0.46 \mathrm{yr}^{-1}$. For the dominating $\mathrm{SG} 3$, with an individual mean production of $0.0076 \mathrm{~g}$ AFDW ind.$^{-1} \mathrm{yr}^{-1}$ and a biomass of $0.021 \mathrm{~g} \mathrm{AFDW} \mathrm{ind} .^{-1}$. the $P / B$ ratio was $0.37 \mathrm{yr}^{-1}$.

\section{DISCUSSION}

The aim of this investigation was to follow in detail the dynamics of Amphiura filiformis and estimate the annual production. The accuracy of such estimates is based on sampling precision, which also is affected by the spatial distribution since it alters the precision. A sampling program is mainly a question of cost, benefit and the purpose of the sampling. A tentative goal of precision of SE being $<25 \%$ of the mean in abundance and biomass was achieved with both the SmithMcIntyre grab and the HAPS corer. The observed spatial distribution of the benthic fauna depends on the size of the sampling unit (Elliott 1977). O'Connor \& McGrath (1979) and O'Connor et al. (1983) used a grab of $0.1 \mathrm{~m}^{2}$, and Ockelmann \& Muus (1978) used a mouse trap sampler of $0.0189 \mathrm{~m}^{2}$. They all reported an aggregated distribution of $A$. filiformis. This is, in part, contradictory to the results presented here; we found a random distribution using the HAPS data but a contagious distribution with the Smith-McIntyre grab. Different densities of the populations, i.e. about 1000 ind. $\mathrm{m}^{-2}$ in Galway Bay and $\varnothing$ resund and about 280 ind. $\mathrm{m}^{-2}$ at this station, could change both the patch dynamics and the relationship between the variance and the mean, as well as spatial distribution, which is affected by the size of the sampling unit (Rosenberg 1974, Andrew \& Mapstone 1987). The inconsistency of spatial distributions in this study should be taken into account when interpreting the results of this investigation. However production estimates are more dependent on the precision of mean values of abundance and biomass than the pattern of variability, which is thus not likely to affect the production estimates significantly.

Accurate assessment of abundance and biomass is essential for high precision of production estimates. Temporal abundance, biomass and size (oral width) stability seems typical for several Amphiura filiformis populations. O'Connor \& McGrath (1979), O'Connor et al. (1983), Duineveld \& Noort (1986), Duineveld et al. (1987), Josefson \& Jensen (1991, 1992) described similar stable population size structures as in this study. A tem- 


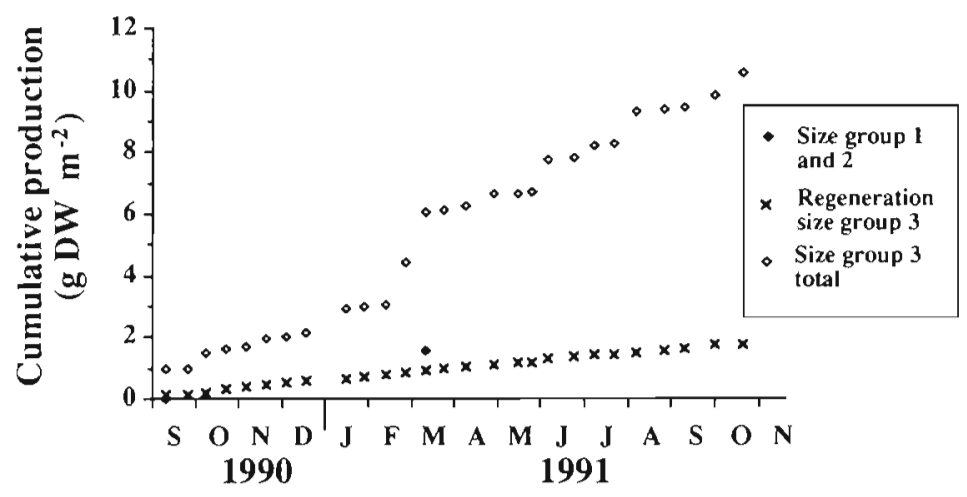

Fig. 9. Amphiura filiformis. Cumulative production for the whole brittle star population and for separated categories. Production for SG 1 \& 2 was calculated when separable for these groups (from 13 September 1990 to 18 March 1991). For the rest of the period, all production is calculated as for SG 3

poral analysis of abundance (nested ANOVA, as described in 'Material and methods') among samples taken between May 1983 and 1991 (data provided from the National Swedish Environmental Monitoring Programme; Fig. 11) from the station studied was undertaken between years and nested 3 yr periods. It showed a significant difference between years ( $\mathrm{df}=6,24 ; F=$ $4.59, \mathrm{p}<0.05$ ), but not between 3 yr periods ( $\mathrm{df}=2,24 ; F$ $=0.76, p>0.05 \mathrm{j}$. The time scale where major changes in total abundance occurred was thus between 1 yr periods.

In $\varnothing$ resund, Muus (1981) found that main settlement was confined to a few weeks in September to November, followed by a rapid decline in abundance of

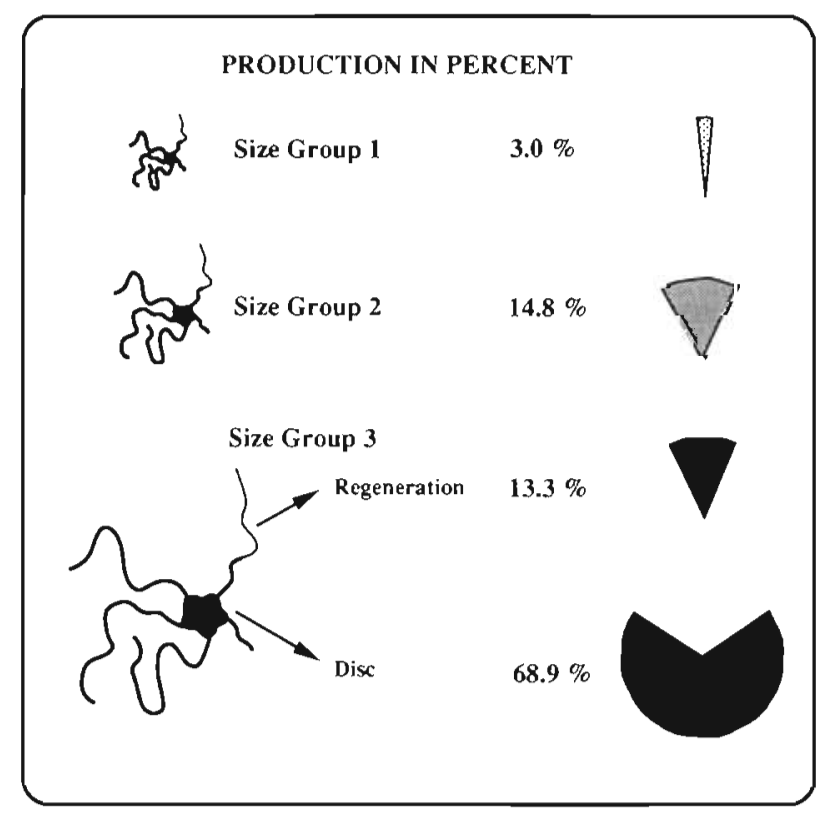

Fig. 10. Amphiura filiformis. Percentage of production for the different size groups of brittle stars based on AFDW values post-larvae. Muus (1981) estimated that brittle stars reached about $4 \mathrm{~mm}$ in disc diameter after 3 to $4 \mathrm{yr}$ and then mixed with the 'adult' population. The annual contribution of juveniles to the adult size group (>4 mm disc diameter) was about $5 \%$ in that investigation. That is about the same proportion of juveniles between 1 and $1.5 \mathrm{~mm}$ (oral width) as that found on 4 November 1991 (Fig. 5). Post-larval mean maximum density in the present investigation $\left(7000\right.$ ind. $\left.\mathrm{m}^{-2}\right)$ was similar to that in the Øresund with maximum mean settlement of about 6500 ind. $\mathrm{m}^{-2}$, but lower than in the North Sea (Duineveld \& Noort 1986) with a maximum of 13000 ind. $\mathrm{m}^{-2}$. The maximum settlement value of 7000 ind. $\mathrm{m}^{-2}$ is a crude estimate ( $\mathrm{SE}=4820$ ), probably a result of patchy settling and low sampling precision from only 2 replicated samples. However patterns similar in these 2 studies were the rapid decline in abundance of postlarvae and the subsequent low presence of juvenile Amphiura filiformis in the population.

The estimated time lag between full gonads and settlement of $88 \mathrm{~d}$ in the present study is comparable to the time period when pelagic larvae have been recorded in the plankton of the northern Øresund in one study from July to November (Fosshagen 1965) and in another from August to December (Thorson 1946). The present finding is only an approximation of the time Amphiura filiformis larvae are found in the pelagic stage. The exact time is difficult to estimate due to the large area of distribution of larvae.

Separation of size groups in Amphiura filiformis is difficult as shown by Muus (1981), O'Connor et al. (1983), Bourgoin \& Guillou (1988), Künitzer (1989) and Josefson \& Jensen (1991). To estimate growth, the MacDonald \& Pitcher (1979) method was used for separating most likely size groups according to a normal distribution, assuming that growth and energy demands were similar for animals of the same size. Estimates of somatic growth were therefore only calculated when noted in the size-frequency histograms (Fig. 5). The growth rates of SG $1\left(0.66 \% \mathrm{~d}^{-1}\right)$ and SG $2\left(0.38 \% \mathrm{~d}^{-1}\right)$ can be compared to estimates of Josefson \& Jensen (1992), which ranged from 0.20 to $1.67 \% \mathrm{~d}^{-1}$ for what they defined as 0 -group $A$. filiformis. The higher estimated values of their investigation may be a result of more rapid growth at that particular station in the Skagerrak, where increased biomass and abundance of $A$. filiformis also have been shown over the period 1972-1988 (Josefson 1990). It may also be an effect of reduced predation since regenerated biomass contributes significantly to the animals' body weight. However, the approach to 


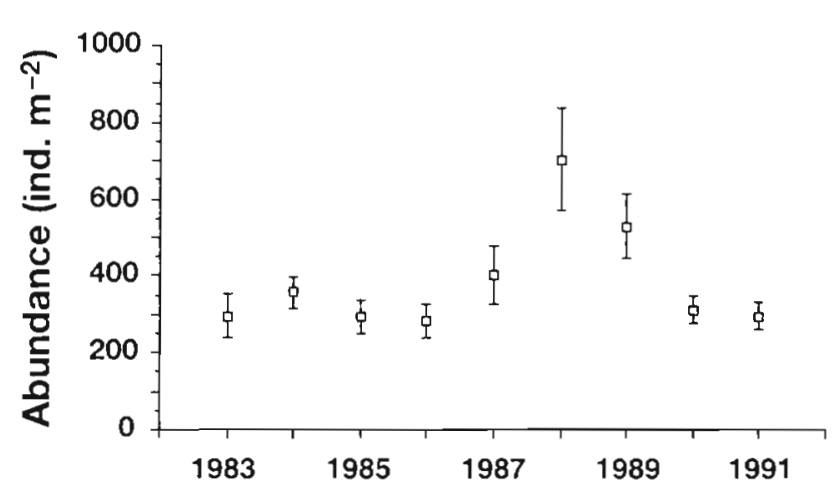

Fig. 11. Amphiura filiformis. Mean ( $\pm \mathrm{SE}$ ) abundance of brittle star at the station studied from 1983 to 1991 (data kindly provided from the National Swedish Environmental Monitoring Programme). Sample size: $0.1 \mathrm{~m}^{2}, \mathrm{n}=5$

fered. Josefson \& Jensen (1992) classified their samples into 2 categories: (1) 1 group of recruits (0-group) and 1 group of adults (1-group); or (2) 1 group of adults only. In the present study the population consisted of 3 size groups plus recruits. More frequent sampling and closer examination of individual biomass in this study are likely to give a higher accuracy in these estimates.

Regenerated production estimates of SG 3 were based on the assumption that an arm grows until it has reached the biomass of an unregenerated arm. This could lead to an overestimation due to breaking of arms when collected and handled. These arms would then be counted as 'regenerating arms'. Lost arms were collected during sorting and constituted 30\% ( $\mathrm{SE}=2.8, n=29$ ) of the cut arms. The origin of these arms, i.e. if they were from outside or inside the HAPS corer or if the arms were under regeneration, is uncertain. Should, however, half of them belong to specimens from inside the sample and not be under regeneration, an overestimation of ca $2.0 \%$ of total production and $11.6 \%$ of regenerated production may be the case. The regeneration rate used in these calculations of $0.0048 \mathrm{mg} \mathrm{DW} \mathrm{arm}^{-1} \mathrm{~d}^{-1}$ (Andreasson 1990) can be compared with O'Connor et al. (1986) who reported a rate of 0.083 and Salzwedel (1974) who found a rate of $0.0071 \mathrm{mg}$ DW arm ${ }^{-1} \mathrm{~d}^{-1}$. The higher rate described by $\mathrm{O}^{\prime}$ Connor et al. is based on preliminary laboratory results, not described in detail. The rate of Salzwedel was measured on Amphiura filiformis fed with microphytoplankton (Dunaliella sp.) which may be too small to be utilised by $A$. filiformis (Ockelmann \& Muus 1978). Andreasson (1990) used natural seston composition and concentrations with flowing deep water and native sediments. The seston concentrations in the experiment varied between 0.98 and $4.81 \mathrm{mg} \mathrm{DW}^{-1}$, or 0.44 and $1.25 \mathrm{mg} \mathrm{AFDW}^{-1}$, which were within the same range as the natural concentration, $5.64 \mathrm{mg} \mathrm{DW} \mathrm{l}^{-1}(\mathrm{SD}=3.28, \mathrm{n}=24)$ or 0.87 mg AFDW $\mathrm{l}^{-1}(\mathrm{SD}=0.40, \mathrm{n}=24)$, in the bottom water at the studied station from 28 August 1990 to 4 November 1991 (own measurements). The seawater in Andreasson's experiment was pumped from $30 \mathrm{~m}$ depth near where the samples in the present investigation were taken. Regeneration rates in the field may differ from those in the laboratory because of differences in the allocation of energy during periods of gonad development, temperature variation, capture efficiency of available food, additional loss of arms, etc. Food availability is most probably a key factor for regeneration rate, and this varies seasonally and between areas. The regeneration rate used in this investigation was a mean regeneration rate estimated over 7 wk under rather realistic conditions.

Temporal linear regression analyses of biomass showed positive correlations with time when separated into size groups (Table 1). This does not show that individual biomass goes up and down, but that the sum of biomass changes is an exponential increase over time for separated size groups. The slopes for separated groups were significant, though less pronounced for SG 3 compared to SG 1 and SG 2. This indicates a declining growth with age within this size interval, as is also described by the von Bertalanffy model based on oral widths (Fig. 8). It could also be an effect of smaller size classes growing into the large SG 3 group. Regenerated biomass showed no increasing trends, but significant fluctuations over the period. This indicates that variables like predation pressure, gonad status and food availability may have influenced the biomass.

Amphiura filiformis populations are often described as stable and mainly composed of large individuals, probably several years old (O'Connor \& McGrath 1979, O'Connor et al. 1983, Duineveld \& Noort 1986, Duineveld et al. 1987, Josefson \& Jensen 1991, 1992). There are examples of relatively rapid changes, caused by high mortality and successive recolonization in areas of fluctuating hydrodynamic conditions, e.g. the Northumberland coast, UK (Buchanan 1967), the Gullmarsfjord in Sweden (Rosenberg 1976) and Concarneau Bay, west France (Bourgoin \& Guillou 1988). Muus (1981) described growth rates for post-larvae up to the size when they were retrieved in a $1 \mathrm{~mm}$ sieve. This is also the approximate size when they change feeding behaviour, from scavengers and predators of meiofauna (Muus 1981) to suspension and deposit feeding (Buchanan 1964, Woodley 1975). This switch coincides with asymmetric and increased growth of 2 of the arms and a change to adult burrowing behaviour. As Muus (1981) suggested, this prolongation of the arms enables the juveniles to take up the adult way of feeding and burrowing earlier. It may also reflect a change in pattern in allocation of energy towards 
growth of arms, which is supported by the findings of this investigation that growth of regenerating arms is an important factor contributing to production of adult A. filiformis

In the complete growth pattern of the benthic stage of Amphiura filiformis, it seems likely that a sigmoidal growth pattern would fit when changes in disc diameter or oral width are used as variables. Consequently, slow growth is observed in juveniles until they have reached a size at which they adopt the more efficient adult feeding behaviour. Later, growth decreases, due to predation of arms and development of gonads. Most 'growth' in an adult brittle star in this study was gonad production and regeneration of arms, which together contributed $82 \%$ of the total production in AFDW; somatic growth of the disc of the adults was small. This conclusion is also supported by the results if disc production is calculated for both negative and positive biomass changes; disc production then equals zero for the adults (SG 3 ).

O'Connor et al. (1986) provided a comparison of $P / B$ ratios for various echinoderms. The ratio of Amphiura filiformis estimated for the large adult size group described from Galway Bay $\left(1.97 \mathrm{yr}^{-1}\right)$ is higher than for the comparable size group (SG 3;0.37 $\mathrm{yr}^{-1}$ ) and for the whole population $\left(0.46 \mathrm{Y}^{-1}\right)$ found in the present study. Glémarec \& Menesguen (1980) estimated a $P / B$ of $2.8 \mathrm{yr}^{-1}$, but also estimated the life span to be $2 \mathrm{yr}$, which is very different from a life span $\geq 20 \mathrm{yr}$, estimated in Galway Bay (O'Connor et al. 1983) and in the $\varnothing$ resund (Muus 1981). A life span of this latter length fits the dynamics of the population investigated here and the estimated von Bertalanffy curve in Fig. 8. The present later growth estimates also approximate those presented by Gage (1990) from Scotland based on counts of arm ossicles correlated to disc diameter.

Losses due to predation can be estimated as the regenerated biomass, which was about $22 \%$ of total biomass. In other studies of fish cropping (cut arms), the proportion of regenerated arms was approximately the same, e.g. 20 to $30 \%$ in Galway Bay (Bowmer \& Keegan 1983) and $20 \%$ in the North Sea (Creutzberg \& Duineveld 1986). Thus, cropping of arms of Amphiura filiformis seems to be an important food source for predators in some marine areas.

Acknowledgements. The authors thank the crew of the RV 'Oscar von Sydow' for help in taking samples; Rod Stevens, Owe Gustafsson, Ninni Pettersson, Birthe Hellman, Bo Bergström and Robert Basin for technical assistance; Björn Tunberg and Odd Lindahl for providing raw data from the National Swedish Environmental Monitoring Programme; Leif Pihl, Alf Josefson, Ib Svane and 3 anonymous reviewers for fruitful comments on the manuscript. Financial support for this study was provided by the Swedish Environmental Protection Agency and the Swedish Natural Research Council.

\section{LITERATURE CITED}

Andreasson, M. (1990). Regenerationshastighet hos Amphiura filiformis (Ophiuoroidae: Echinodermata). B.Sc. thesis University of Goteborg (in Swedish)

Andrew, N. L., Mapstone, B. D. (1987). Sampling and the description of spatial pattern in marine ecology. Oceanogr. mar. Biol. A. Rev. 25: 39-90

Baden, S. P., Pihl, L., Rosenberg, R. (1990). Effects of oxygen depletion on the ecology, blood physiology and fishery of the Norway lobster Nephrops norvegicus. Mar. Ecol. Prog. Ser. 67: 141-155

Bourgoin, A., Gullou, M. (1988). Démographie d'Amphiura filiformis (Echinodermata Ophiuroidea) en baie de Concarneau (Finistère, France). Oceanol. Acta 11: 79-88

Bowmer, T., Keegan, B. F. (1983). Field survey of the occurrence and significance of regeneration in Amphiura filiformis (Echinodermata: Ophiuroidea) from Galway Bay, west coast of Ireland. Mar. Biol. 74: 65-71

Buchanan, J. B. (1964). A comparative study of some features of the biology of Amphiura filiformis and Amphiura chiajei (Ophiuroidea) considered in relation to their distribution. J. mar. biol. Ass. U.K. 44: 565-576

Buchanan, J. B. (1967). Dispersion and demography of some infaunal echinoderm populations. Symp. zool. Soc. Lond 20: $1-11$

Creutzberg, F., Duineveld, C. G. A. (1986). The role of the lesser weever Trachinus vipera and the dab Limanda limanda in the benthic system of the southern North Sea. Demersal Fish Committee. Comm. Meet. int. Coun Explor. Sea ICES.-C.M. L. 4: 1-9

Crisp, D. J. (1984). Energy flow measurements. In: Holme. N. A., Mclntyre, A. D. (eds.) Methods for the study of the marine benthos. Blackwell Scientific Publications, Oxford p. $284-372$

Duineveld, G. C. A., Künitzer, A., Heyman, R. P. (1987) Amphiura filiformis (Ophiuroidea: Echinodermata) in the North Sea. Distribution, present and former abundance and size composition. Neth. J. Sea Res. 21: 317-329

Duineveld, G. C. A., Noort, G. J. v. (1986). Observations on the population dynamics of Amphiura filiformis (Ophiuroidea: Echinodermata) in the southern North Sea and its exploitation by the dab, Limanda limanda. Neth. J. Sea Res. 20: $85-94$

Elliott, J. M. (1977). Some methods for the statistical analysis of samples of benthic invertebrates. Titus Wilson \& Son Ltd, Kendal

Fosshagen, A. (1965). Bunnevertebratlarver over et Venussamfunn i Öresund. M.Sc. thesis, University of Bergen (in Norwegian)

Gage, J D. (1990). Skeletal growth bands in brittle stars microstructure and significance as age markers. J. mar. biol. Ass. U.K. 70: 209-224

Glémarec, M., Menesguen, A. (1980). Functioning of a muddy sand ecosystem: seasonal fluctuations of different trophic levels and difficulties in estimating production of the dominant macrofauna species. University of South Carolina Press, Columbia

Hedges, J. 1., Stern, J. H. (1983). Carbon and nitrogen determinations of carbonate-containing solids. Limnol. Oceanogr. 29: $657-663$

Josefson, A. B. (1990). Increase of benthic biomass in the Skagerrak-Kattegat during the 1970 s and 1980 s - effects of organic enrichment. Mar. Ecol. Prog. Ser. 66: 117-130

Josefson, A. B., Jensen, J. N. (1991). Benthic dynamics in the Skagerrak-Kattegat area suggest major importance of largescale, pelagic production related factors. Cooperation 
européenne dans la domaine de la Recherche Scientifique et Technique, Galway, Ireland. COST 647 Coastal benthic ecology activity report 1988-1991, p. 414

Josefson, A. B., Jensen, J. N. (1992). Growth patterns of Amphiura filiformis support the hypothesis of organic enrichment in the Skagerrak-Kattegat area. Mar. Biol. 112: 615-624

Josefson, A. B., Rosenberg, R. (1988). Long-term soft-bottom faunal changes in three shallow fjords, west Sweden Neth. J. Sea Res. 22 (2): 149-159

Kanneworff, E., Nicolaisen, W. (1973). The 'HAPS' A framesupported bottom corer. Ophelia 10: 119-128

Krumbein, W. C., Pettijohn, F. J. (1938). Manual of sedimentary petrography. Appleton-Century, Inc. New York

Künitzer, A. (1989). Factors affecting the population dynamics of Amphiura filiformis (Echinodermata: Ophiuroidea) and Mysella bidentata (Bivalvia: Galeommatacea) in the North Sea. In: Ryland, J. S., Tyler, P. A. (eds.) Proc. 23rd Eur. mar. Biol. Symp. Olsen \& Olsen, Fredensborg, p. 395-406

Lindahl, O., Andersson, B., Davidsson, L. (1991). Pelagial monitoring i Gullmarsområdet. Cont. no. 3948, Swedish Environmental Protection Agency, Solna, p. 1-35

MacDonald, P. D. M., Pitcher, T J. (1979). Age groups from size-frequency data: a versatile and efficient method of analysing distribution mixtures. J. Fish. Res. Bd Can. 36 : $987-1001$

Mattson, S. (1992). Food and feeding habits of fish species over a sublittoral bottom in the north-east Atlantic. 3 Haddock [Melanogrammus aeglefinus (L.)] (Gadidae). Sarsia 77: 33-45

Morrisey, D. J., Underwood, A. J., Howitt, L., Stark, J. S. (1992). Temporal variation in soft-sediment benthos. J. exp. mar. Biol. Ecol. 164: 233-245

Muus, K. (1981). Density and growth of juvenile Amphiura filiformis (Ophiuroidea) in the Oresund. Ophelia 20: $153-168$

O'Connor, B., Bowmer, T., Grehan, A. (1983). Long-term assessment of the population dynamics of Amphiura filiformis (Echinodermata: Ophiuroidea) in Galway Bay (west coast of Ireland). Mar. Biol. 75: 279-28

O'Connor, B., Bowmer, T., McGrath, D., Raine, R. (1986). Energy flow through an Amphiura filiformis (Ophiuroidea: Echinodermata) population in Galway Bay, west coast of Ireland: a preliminary investigation. Ophelia 26: $351-357$

O'Connor, B., McGrath, D. (1979). The population dynamics of Amphiura filiformis (O. F. Müller) in Galway Bay,

This article was submitted to the editor west coast of Ireland. In: Balkema, A. A. (ed.) Proceedings of the European Colloquium on Echinoderms. A. A. Balkema, Rotterdam, p. 219-222

Ockelmann, K. W., Muus, K. (1978). The biology, ecology and behaviour of the bivalve Mysella bidentata (Montagu). Ophelia 17: 1-93

Pearson, T. H., Josefson, A. B., Rosenberg, R. (1985). Petersen's benthic stations revisited. I. Is the Kattegat becoming eutrophic? J. exp. mar. Biol. Ecol. 92: 157-206

Petersen, C. G. J. (1913). Havets bonitering. II Om havebundens dyresamfund og om disses betydning for den marine zoogeografi. Beret. Minist. Landbr. Fisk. dan. biol. Str 21: 1-68

Ricker, W. E. (1979). Growth rates and models. In: Hoar, W. S., Randall, D. J., Brett, D. J. (eds.) Fish physiology. Vol. 3. Academic Press, Inc., New York, p. 678-743

Rosenberg, R. (1974). Spatial dispersion of an estuarine benthic faunal community. J. exp. mar. Biol. Ecol. 15: 69-80

Rosenberg, R. (1976). Benthic faunal dynamics during succession following pollution abatement in a Swedish estuary. Oikos 27: 414-427

Rosenberg, R., Loo, L. O. (1988). Marine eutrophication induced oxygen deficiency: effects on soft bottom fauna, western Sweden. Ophelia 29: 213-225

Rosenberg, R., Loo, L. O., Möller, P. (1992). Hypoxia, salinity and temperature as structuring factors for marine benthic communities in a eutrophic area. Neth. J. Sea Res. 30: $121-129$

Salzwedel, H. (1974). Arm regeneration bei Amphiura filiformis (Ophiuroidea). Veröff. Inst. Meeresforsch. Bremerhaven 14: 161-1.67

Sokal, R. R., Rohlf, F. J. (1981). Biometry. W. H. Freeman \& Co., San Francisco

Thorson, G. (1946). Reproduction and larval development of Danish marine bottom invertebrates. Meddr. Danm. Fisk.og Havunders. Ser.: Plankton 4: 451-454

Tunberg, B. (1990). Overvakning av mjukbottenfauna längs Sveriges västkust. Cont. no. 3936, Swedish Environmental Protection Agency, Solna, p. 1-93

Underwood, A. J. (1981). Techniques of analysis of variance in experimental marine biology and ecology. Oceanogr. mar. Biol. A. Rev. 19: 513-605

von Bertalanffy, L. (1934). Untersuchungen über die Gesetzlichkeit des Wachstums. 1. Teil. Arch. Entwicklungsmech. Org. 131: 613-652

Woodley, J. D. (1975). The behaviour of some amphiurid brittle stars. J. exp. mar. Biol. Ecol. 18: 29-46

Manuscript first received: December 4, 1992

Revised version accepted: September 20, 1993 